\title{
Ten years of academic psychiatry at Keele
}

\section{Going to sea in a sieve}

\author{
Jed Boardman
}

Academic psychiatry at Keele University reached its 10th birthday in 1996. In 1986 John Cox was appointed to the foundation Chair of Psychiatry in what was then the Department of Postgraduate Medicine (Cox, 1990; Barrett, 1991). The School of Postgraduate Medicine was established in 1989 and along with it a formal Department of Psychiatry. There is no undergraduate medical school at Keele and the School of Postgraduate Medicine, with 14 full Professorships, is now the largest in the United Kingdom, outside of London. The Department of Psychiatry has expanded in size since 1989 and has one Professor of Psychiatry, four Senior Lecturers and two Lecturers. With its busy MRCPsych teaching programme, a Diploma and MSc in General Psychiatry and research activity it has made a significant contribution to the raising of the standards of North Staffordshire psychiatry. From its small beginnings it has now attained a national and international profile.

At our 10th Birthday party earlier this year one of our local poets, Tamar Hodes, composed and read an ode to the department. With apologies to Edward Lear, and to those who may not recognise all the names contained therein, we would like to share this poem and wonder whether such a poetic dedication is another first for our department.

\section{References}

BARRETT, K. (1991) Postgraduate teaching in the Department of Psychiatry. University of Keele. Psychiatric Bulletin. 15, 19-21.

Cox. J. L. (1990) Psychiatry at Keele: germination of a new department. Psychiatric Bulletin, 14, 489-490.

JED BOARDMAN, Head of Department of Psychiatry and Senior Lecturer in Social Psychiatry, Keele University, Stoke-on-Trent ST4 7QB

\section{The Academic Psychiatry Department, Keele (with apologies to Edward Lear's 'They Went to Sea in a Sieve')}

They built an academic psychiatry department. A department good and strong.

Though everyone said it couldn't be done, They worked so hard and they worked so long For a department good and strong. And they built it out of cedar wood And did the best job that they could Because they believed that they were true And that you do what you have to do Oh, that department good and strong.

Chorus: Ten years on, ten years on, In weather foul or fair. Its crew is brave on that voyage long With John the cox in the chair!

At first there were psychiatrists there, Namely Tony and Ted.

Then Mike, David, Steve and Ken.

Roger, Carol, Bruce and then Sandra and Richard and Jed. And Fiona, Kevin, Ilana and Stephen, Chris and Bodie to make it even.

They all set sail on a stormy day

Determined to voyage along their way

With John the cox at the head!

Chorus: Ten years on, ten years on, In weather foul or fair. Its crew is brave on that voyage long With John the cox in the chair!

And they sailed that department, yes, they did, Though the storms were bad and the weather rough.

And the lightning struck and the budgets were cut,

They were sometimes despondent at night - but They survived though the going was tough. And what an achievement, yes, indeed, 
In times of economic need

To journey on with strength and cheer About to start their eleventh year And strut their funky stuff.

Chorus: Ten years on, ten years on, In weather foul or fair. Its crew is brave on that voyage long With John the cox in the chair!

And we wish them luck, this hardy crew, For their future does seem bright. They're all determined to do their best And to work non-stop without a rest And to carry on their fight.
There is no vessel in which they won't travel. No dilemma they can't unravel. There are no two patients quite the same And no condition they cannot name. Now we bid you all goodnight with -

Chorus: Ten years on, ten years on, In weather foul or fair. Its crew is brave on that voyage long With John the cox in the chair!

TAMAR HODES

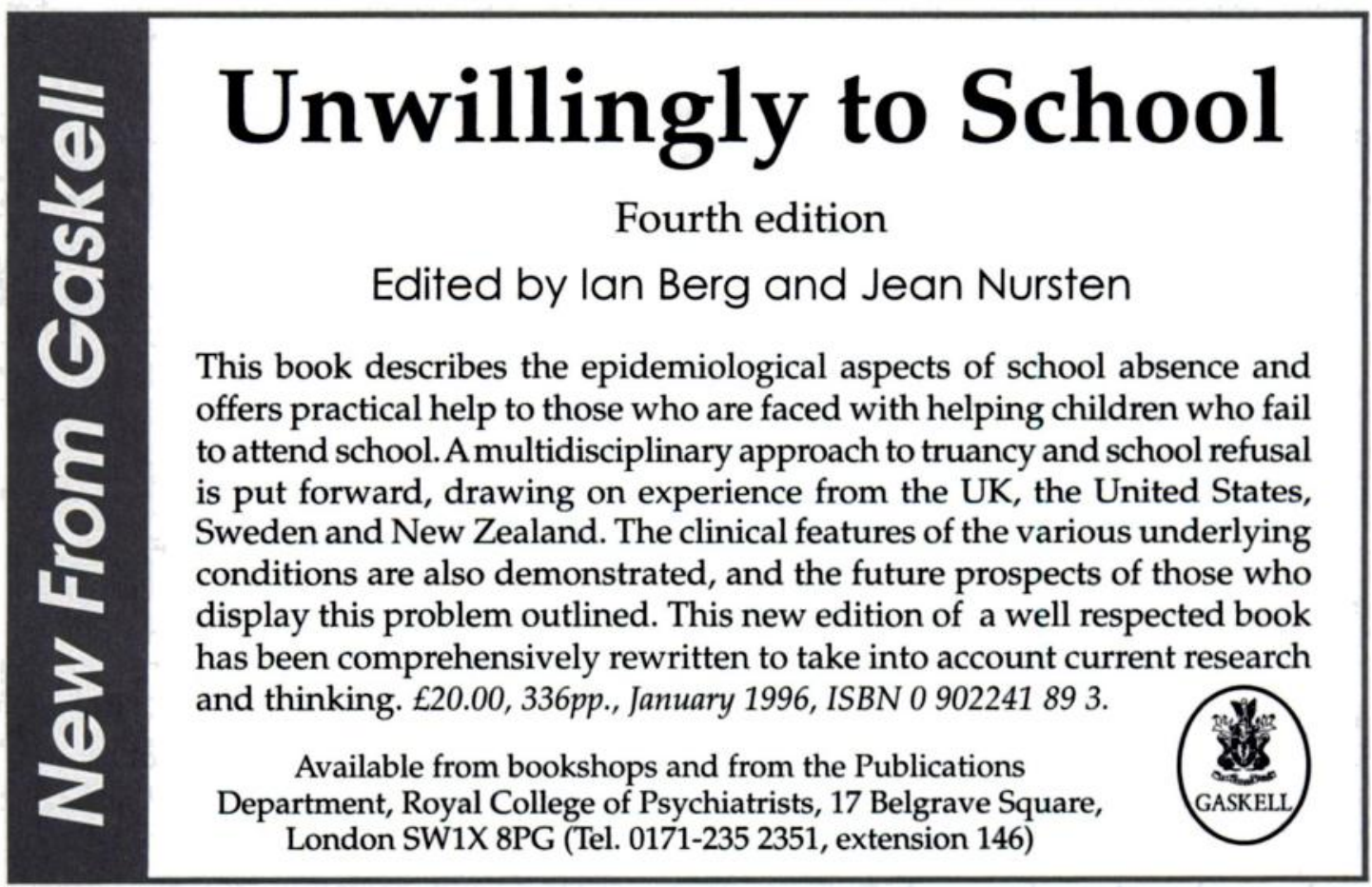

